Trabajos de Geología, Universidad de Oviedo, 35 : 7-18 (2015)

\title{
Measure of the color of beach nourishment sands: A case study from the Belgium coast
}

\section{Medida del color de las arenas de reposición de una playa: un estudio de la costa de Bélgica}

\author{
Victor Cardenes ${ }^{1}$ y Álvaro Rubio ${ }^{2}$ \\ ${ }^{1}$ Department of Geology and Soil Science, Ghent University, Krijgslaan 281, S8, 9000 Ghent, Belgium \\ (e-mail: victor.cardenes@ugent.be) \\ ${ }^{2}$ Departamento de Geología, Universidad de Oviedo, C/Jesús Arias de Velasco s/n, 33005 Oviedo, Asturias, Spain \\ (e-mail:arubio@geol.uniovi.es)
}

\begin{abstract}
The aesthetical perception of a beach as a recreational place is closely linked to the sand color. This is one of the most perceptible characteristics of a beach. Sand color can be altered after a nourishment work. This type of works is becoming more and more popular since they represent a good tool for preserving beaches from erosion. However, only little (or none) attention has been paid to sand color during nourishment works. Colors of the sands from the Belgian coast were determined in the CIELAB space, together with their granulometry and composition. Color coordinates range between 50 and 60 for $\mathrm{L}^{*}, 0.5$ to 4.0 for $\mathrm{a}^{*}$, and 10.5 to 16.5 for $\mathrm{b}^{*}$. The composition shows a dominant quartz fraction, followed by shell fragments and finally rock fragments. Granulometry is rather homogeneous, being the grain distribution for the east part of the coast narrower than for the west coast. This work describes the methodology for performing colorimetric analysis in sand beaches before a nourishment work, together with the main acceptance criteria when choosing the appropriate sand for replacement.
\end{abstract}

Keywords: Sand color, granulometry, nourishment, CiELAB.

Resumen: La percepción estética de una playa como lugar de recreo está estrechamente ligada al color de la arena. Esta es una de las características más perceptibles de una playa. El color de la arena puede ser alterado después de un trabajo de reposición. Este tipo de obras son cada vez más populares ya que representan una buena herramienta para preservar las playas de la erosión. Sin embargo, se ha prestado poca (o ninguna) atención al color de la arena durante los trabajos de reposición. Los colores de las arenas de la costa belga fueron determinados en el espacio Cielab, junto con su granulometría y composición. Las coordenadas de color varían entre 50 y 60 para L*, 0,5 a 4,0 para $a^{*}$ y 10,5 a 16,5 para $b^{*}$. La composición muestra una fracción de cuarzo dominante, seguida de fragmentos de conchas y finalmente fragmentos de roca. La granulometría es bastante homogénea, siendo la distribución de grano más estrecha para la parte este de la costa que para la costa oeste. Este trabajo describe la metodología para realizar el análisis colorimétrico en playas de arena antes de un trabajo de reposición, junto con los principales criterios de aceptación al escoger la arena adecuada para el reemplazo.

Palabras clave: Color de arena, granulometría, reposición, Cielab. 
One of the most popular actions on a beach is nourishment, in order to maintain the beach line for several purposes (recreational, littoral dynamic, conservation, etc.). It is desirably that nourishment sands come from offshore, so the composition and aesthetics of the sand is similar to that from the beach, but in some cases this new sand comes from other places (Charlier et al., 1989; de Meyer 1989; Anthony et al., 2011; Cooke et al., 2012). Then it is possible that the difference between original and new sand is perceptible by the human eye, delivering into aesthetic conflicts with the coastal landscape. Different nourishment sand color can lead to disagreement and rejection from the beach users, which may suppose important economic losses for the local economy. At least in one documented case the nourishment works were taken to court for this reason (Pranzini et al., 2010). In other cases, changes on the mineralogy of nourishment sand can even alter the nesting conditions for marine organisms, as for the case of loggerhead turtles (Milton et al., 1997). According to Charlier et al. (1989), the sand selected for a nourishment project should be at least as texturally coarse as the original beach material. The optimal textural characteristics are coarser grain and a selection better than the original sand. Capobianco et al. (2002) indicate that the finest fractions of the nourishment sand may result cohesive, being then more resilient to dynamic changes, while coarser fractions are more mobile. This should be taken into account when planning the position of the sand on the beach, depending on the specific nourishment model to be developed. The success of a nourishment work then depends on a great extent on the granulometry of the refill sand. For the case of the Nice beach, nourishment works did not take the desired effect due to a lack of coarse sizes (gravel) on the refill, even when the total volume of the operation was one of the most significant in the world (Anthony et al., 2011). Beach sand porosity is assumed to be close to $40 \%$, but this value changes after a nourishment work. The beach dynamics tend always to homogenization of the sediment with time. Detailed characterization of the porosity of the refill sand should be accomplished in order to achieve the optimal performance of the nourishment tasks (Roman-Sierra et al., 2014).

Belgium coast is highly antrophized since historical times. It has an approximate extension of $67 \mathrm{~km}$, with dense human occupancy, and can be divided in Western and Eastern coasts, being the locality of Ostend the dividing point. Protective groins and seawalls are settled in most of the coast longitude, but in areas with remaining dune systems. Since the end of the XX century, beach erosion has evolved to be more and more aggressive, probably becoming the most important problem in Belgium coast management (Charlier et al., 1989; de Meyer 1989; Charlier et al., 1992; Hamm et al., 2002; Hanson et al., 2002; Charlier et al., 2005). The Belgium coast has been object of continuous works against the action of the sea since centuries (Charlier $e t$ al., 2005). But it was after an exceptionally severe storm held in 1953 (Charlier et al., 2000) when most of the actual coastal defenses against erosion (groins and seawall) were made. However, these protective measures needed continuous repairs and did not completely stop the loss of sand. A milestone in the Belgium coast management was held in 1979, when the beginning of the works of the new Zeebrugge harbor. During these works, sand dredged from the construction of the offshore channel were used for nourishment (de Meyer 1989). An estimated volume of 8.4 million $\mathrm{m}^{3}$ sand was spread over $8.2 \mathrm{~km}$ of linear distance. These works were the most voluminous nourishment action held up to that date. In the following years, nourishment works continued when needed, especially after storm episodes, with good results. Nowadays, Belgium coast is managed with periodical nourishment works, together with maintenance of the defensive structures.

\section{Beach colors}

Color of the sand is one of the most important aesthetic attributes of a beach. Yet Herodoto (IV century B.C.) describes, in his book Polimnia, the color of the sands of Leuca Acta (white beach) of Tracia. The color of a beach depends on the grain size, the nature of the source rock, and the amount of shell fragments from marine organisms. The most abundant minerals in beach sands are quartz and feldspar, due to their resistance to the erosion and abrasion processes held during the geological cycle. Quartz is usually of light tones, while feldspars color depends on their chemical composition, but are often of light tones too. Dark tones in a beach sand are given by the presence of heavy minerals 
(Hobbs 2012), with a specific gravity higher than 2.89. Some of the most typical heavy minerals are iron oxides and garnets, which usually confer a reddish hue (Walden et al., 1997). Swift et al. (1972) found a correlation between grain size and color in sands from the Virginia Shelf. Coarse and medium grain-sized sands have brown hue, while fine and very fine grain-sized sands have olive to grey hue. These authors link the color to the existence of iron oxide pigmentation, which depends on the zone of the shelf.

Generally speaking, color of beaches is usually of orange-yellow tones, but there are numerous singular beaches around the world with other different colors, like Seaman's Beach (Australia), of white color, Papakolea Beach (Hawaii), of green color, Harbor Island beach (Bahamas), of pink color, Ramla il-Hamra beach (Malta), of orange color, Kaihalulu beach (Galapagos), of red color, and Nauset beach (USA), of black color. These beaches are only a small representation of the wide variety of colors that the beach sand can present. Then, the color of the sand is one of the most important characteristics of a beach, not only from the aesthetical point of view. The sand temperature is determined by the amount of solar radiation and how much of this radiation is absorbed by the sand. Dark colors absorb much more solar radiation than light colors. This influences different features, such as the wind dynamics (Hobbs 2012) and biota. On the other hand, sand color must be taken into account when performing analysis of suspended particle analysis with optical backscatter sensors. Results of the analysis can differ for sands with all remaining parameters equal, due to the different wavelengths response depending on color (Hatcher et al., 2000).

From a recreational point of view, sand color is very important for the users of the coast, since it is an important part of the picture of a leisure day at the beach (Roca et al., 2008). This fact has to be taken into account when facing a nourishment work. A sort of natural nourishment process are tsunamis, which bring together huge amounts of sands from different places. After the Tohoku tsunami in 2011, the color of the sand beaches considerably changed (Tsujimoto et al., 2013). Until sorting mechanisms have not properly developed, color of nourishment sand is different from the original sand, and even then it can take several years to homogenize.

There is a real need for a systematic and standardized characterization of nourishment sand color (Pranzini et al., 2011). This is an aspect generally not taken into account when undertaking a nourishment work, but which undoubtedly has a great importance from an aesthetical point of view. As a preliminary approach, these authors used both Munsell and Cielab color spaces. Munsell system is widely used in soil determination, consisting in a colored tile scale used for visual comparison with the samples. Results depend on factors like the operator's perception, the illumination conditions, and the size of the sample, among others. On the other hand, the CielaB color space determination is performed with a colorimeter, and it is not influenced by external factors. These devices have become more and more portable and cheap with the years.

This work deals with the color characterization of nourishment sands for the case of the Belgian coast. For this purpose, a methodology of measuring was developed.

\section{Methodology}

Sands were sampled at different points of the Belgium coast. At first, points were marked on a digital map using the cartographic database MapSource 6.16.3 for Belgium, and then transferred to a GPS device Garmin eTrex Legend HCx. Points were chosen with an average distance of 2-3 km between them. It is known that granulometry varies along the beach profile, so samples were picked always at the same point of the profile, just before the berm ridge at the foreshore area (Fig. 1). At this point color showed to be quite uniform. Since Belgium coast is severely antrophized, most of the points were easily to reach, with some small problems at the river mouths. Sampling was held in August 2014, and it took a couple of days. In total, 31 samples of sand were picked (Fig. 2). At the Sedimentology Laboratory of Ghent University, samples were cleaned with distilled water and dried in a ventilated oven for 24 $\mathrm{h}$, at a temperature of $110^{\circ} \mathrm{C}$. Granulometric anal- 
ysis were held using sieve sizes between -1 and $4 \phi$ scale, corresponding to the interval for sands.

Colorimetric analyses were performed with a Minolta CR 400 colorimeter at Oviedo University, Spain. This instrument is designed to perform a diffusion illumination of $0^{\circ}\left(\mathrm{d} / 0^{\circ}\right)$, which means that the object is illuminated from all directions by several illuminants of virtually similar brightness. The reflected light is received vertically to the sample surface. In normal conditions, color perception of objects is a conjunction of perceptions of multiple light sources and reflections. The colorimeter is able to reproduce these conditions during the measurements. Each sand sample was deposited in a Petri dish of $150 \mathrm{~mm}$ diameter, whit an area close to $95 \mathrm{~cm}^{2}$. The surface of each sand was carefully leveled before the measures. The device was attached to a metal structure, so it remained still while the Petri dish was moved freely by the operator (Fig. 3). The colorimeter was operated through a laptop using the program Spectramagic NX v. 2.1.

Measures were randomly taken all over the area. Working conditions of the device were: diameter
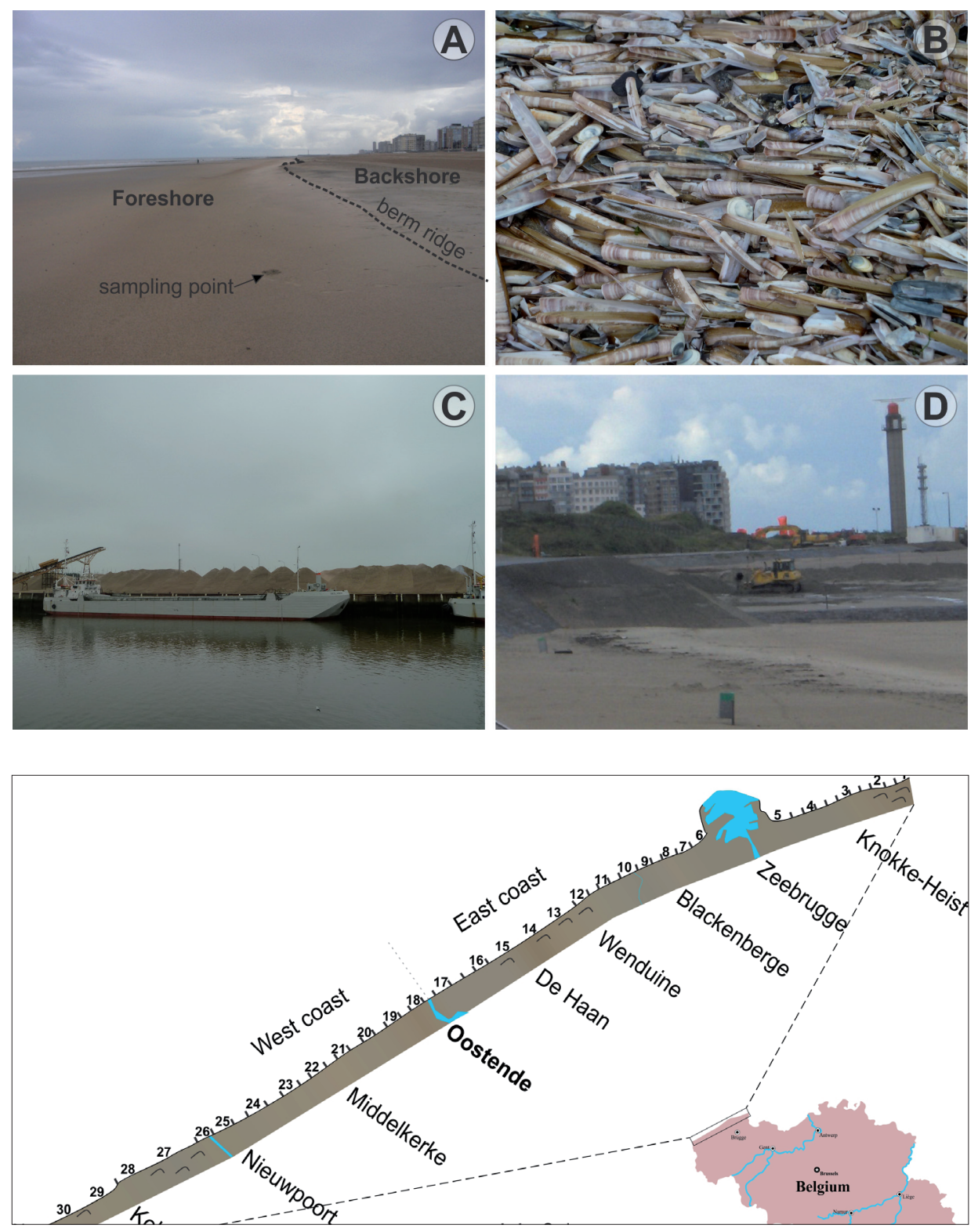

Figure 1. A) Sampling point with respect to the beach profile, Ostend. B) Image of shells accumulation close to Ostend. Different species of bivalve mollusks can be recognized, such as sword razor (Ensis ensis), mussel (Mitylus sp.) and clam (Angulus fabula). C) Accumulation of sands dragged from offshore waiting for the nourishment works, Nieuwpoort. D) Beach nourishment projects at the Zeebrugge harbor.

Figure 2. Location of the sampling points along the Belgian coast. 
viewing aperture of $50 \mathrm{~mm}$, CIE standard daylight illuminant D65 and observer $2^{\circ}$, with the Specular Component Included (SCI mode). Then, color measures were done according to the CIE 1976 (L*, $\mathrm{a}^{*}, \mathrm{~b}^{*}$ ) color space, commonly known as Cielab. In this system, each color is represented by three main scalar parameters that correspond to Cartesian coordinates: $\mathrm{L}^{*}$ lightness or luminosity, ranging from 0 (absolute black) to 100 (absolute white), a* corresponds to changes in the red-green colors, being positive values for red, and negative values for green, and $\mathrm{b}^{*}$ corresponds to changes in the yellow-blue colors, being positive values for yellow and negative values for blue. These parameters can also be repre-

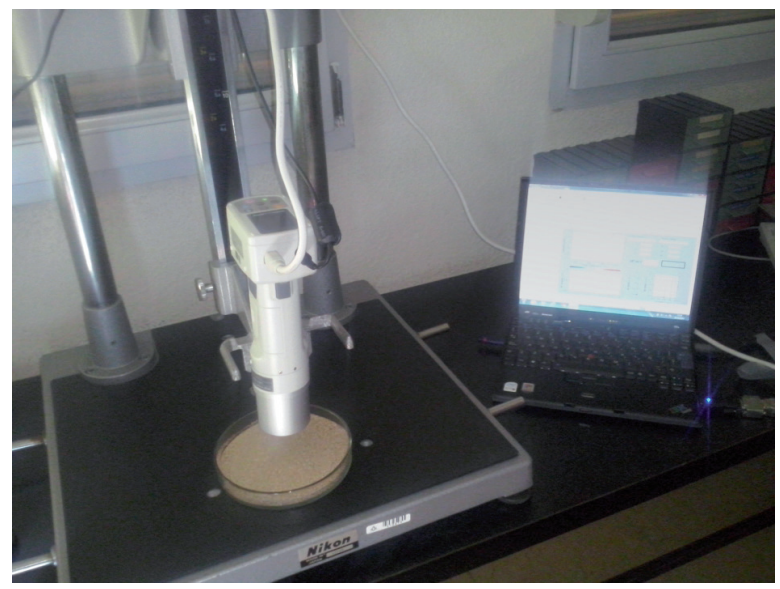

Figure 3. Setup of the device for the color measurements.

sented in other space color, CIELCH, more closely linked to the psychophysical perception of the color: $\mathrm{L}^{*}$ lightness remains the same as for the Cartesian coordinates; $\mathrm{C}^{*} \mathrm{ab}$ is the chroma, meaning the intensity of color or saturation, being calculated by the formula

$\mathrm{C}^{*} \mathrm{ab}=\left(\mathrm{a}^{* 2}+\mathrm{b}^{* 2}\right)^{1 / 2}$

and $h_{a b}$, the hue angle or tone of color which refers to the main wavelength, being calculated by the formula

$\mathrm{h}_{\mathrm{ab}}=\arctan \left(\mathrm{b}^{*} / \mathrm{a}^{*}\right)$

This value shows the redness, yellowness, greenness, or blueness on a circular scale, starting at $0^{\circ}$ and increasing counterclockwise (Wyszecki et al., 1982).
Coordinates from the Cielab space can give the numerical quantification of the difference of color between two objects, and thus predict if that color difference will be or not noticeable to human eye. This is performed through the calculation of the Increment of Energy $(\Delta \mathrm{E})$. The calculation of this parameter has been improved since its definition in 1976. It is generally accepted that a $\Delta \mathrm{E}>2.3$ consists in a "just noticeable difference" (JND), representing the limit in which the human eye will catch the difference between two colors. However, this perception depends on many factors, like the color themselves, the environment and the physical state of the observer, among others. In this work, $\triangle \mathrm{E}$ was calculated according to the formula CIEDE2000 (CIE_TC_1-57 2013). Calculations were made with the $\mathrm{Excel}^{\odot}$ worksheet for Windows CCCEn. $x l s$ (Boronkay, 2014). This worksheet allows quickly and easily calculate conversions between the different color spaces and chromatic color differences.

To guarantee that the measures were representative, the Representative Elementary Area (REA) was calculated. The REA can be defined as the minimum area of sample required from which a given parameter measurement, color in this case, becomes independent of the size of the sample. It can be graphically calculated by the point at which the accumulated curve becomes stable (Fig. 4). For this work, and taking into account that there is no high compositional variation of the samples along the coast, the minimum number of measures for each sample was 21 .

Mineralogical composition was calculated by naked eye examination with a binocular magnifier Leica wild M10 with coupled camera Leica DF300, giving estimated percentages of the three main groups of components: quartz (leucocratic component), rock fragments and shell fragments (melanocratic components). Quartz is one of most abundant minerals on Earth's crust, and, due to their resilience along the geological cycles, it constitutes the main component of most types of sands. Normally it presents light colors, from white to transparent. In this work, all the mineral grains with white tones, or leucocratic, were considered to be quartz during the counting. Rock fragments comprise all other rocky fragments, with many different colors. Shell fragments group com- 

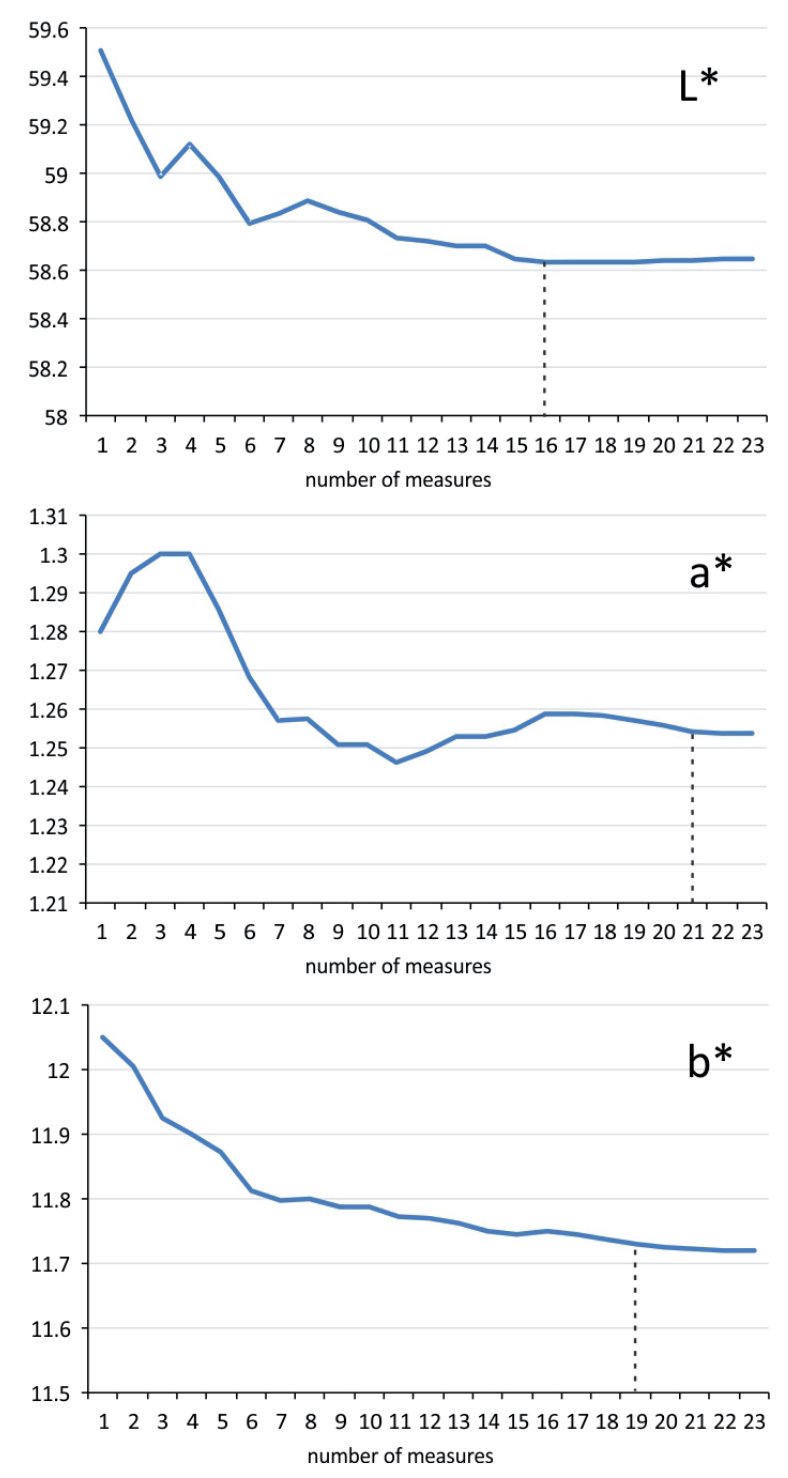

Figure 4. REA values are different for each color coordinate. The highest number of measures needed to achieve stability is 21 , corresponding to the $\mathrm{a}^{*}$ coordinate.

prises rests of marine organisms that contribute to the sand composition. They are melanocratic, but easily distinguishable from the mineral components. For each sample, several visual estimations were made, and then the values were averaged and recalculated to $100 \%$.

Finally, numerical data were statically treated with the software SPSS v 15.0 for Windows, in order to find any possible correlations between the different parameters. The statistic selected for this purpose was the Pearson product-moment correlation coefficient. This coefficient represents a measure of the linear correlation between a group of variables.

\section{Results}

Data for colorimetric analysis and mineral proportions can be found at Table I. All samples collected can be texturally classified as sands, in the grain size interval between -1 and $4 \phi$ scale (Fig. 5). However, there are some slight differences. Samples from the W coast present a wider range of distribution both to coarse and fine terms, while samples from the $\mathrm{E}$ coast are more clustered.

Visual analysis of the grains show quartz and rock grains have a perceptible higher roundness than shell fragments, consequence of their transportation from the source area to the beach. Shell fragments have not suffered such transportation, since the source area is the beach itself, so they have many different shapes, showing none or few rounding (Fig. 6). The quartz fraction is clearly predominant in most of the samples (Table I), similar to the proportions described by (Anthony et al. 2007) for sands from the neighboring French coast.

Regarding to colorimetric analysis, values for $\mathrm{L}^{*} \mathrm{pa}-$ rameter are comprised between 60.65 and 52.76, with an average standard deviation of $1.81, \mathrm{a}^{*}$ parameter ranges between 3.91 and 0.66 , average standard deviation 0.85 , and $b^{*}$ ranges between 16.56 and $10.62,1.56$ average standard deviation. All samples have very similar colors, although two groups can be distinguished: coarse sands, with more red-yellow tones, and fine sands, with tones tending to green. The color difference for the two most dissimilar sands, samples 1 and 29 , is $\Delta \mathrm{E}=7.45$, which corresponds to a noticeable color difference to human eye. These two sands also present a rather different granulometry, being 1 much coarser than 29 (Table I). This color difference can be inferred from the $L^{*}$ versus $\mathrm{C}^{*}$ ab graphic (Fig. 7), in the distance between upper and lower samples for the $\mathrm{Y}\left(\mathrm{L}^{*}\right)$ axis. In these sands, difference in $\mathrm{L}^{*}$ plays a more important role than differences in $\mathrm{a}^{*}$ and $\mathrm{b}^{*}$ parameters, regarding to human eye noticeable color differences. However, 


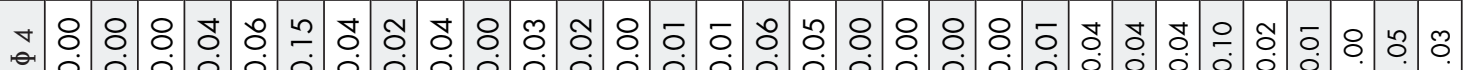

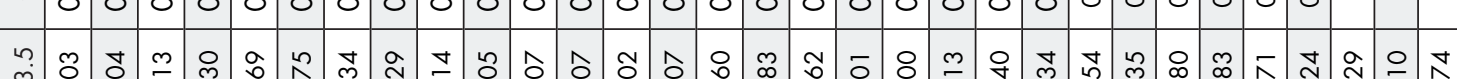

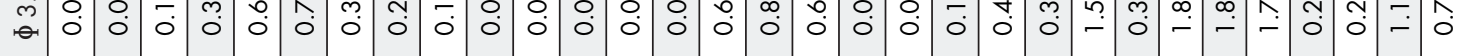

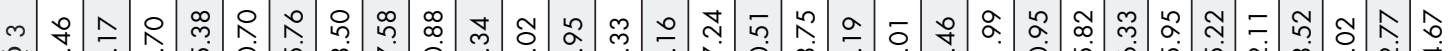

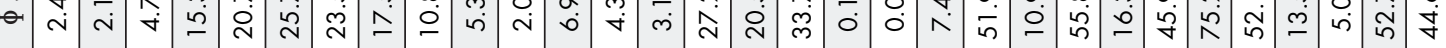

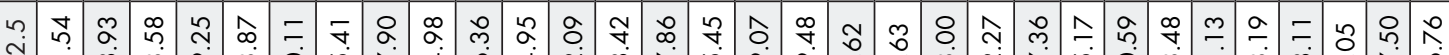
• $\sim ⿻ 上 丨)$ • $\stackrel{\sim}{\circ}$ 이 •

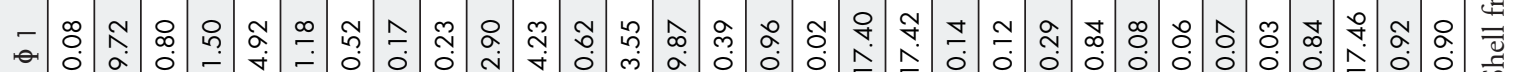

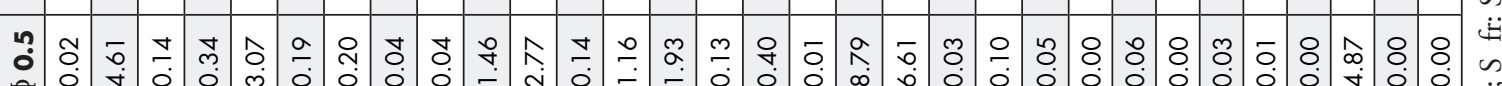

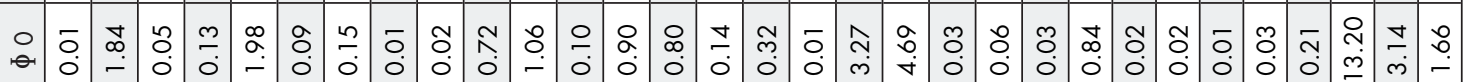

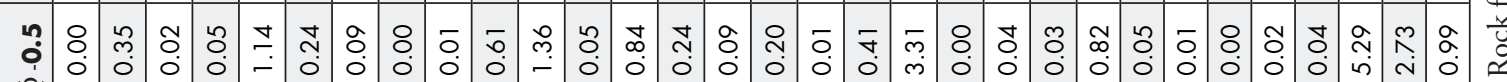
- •

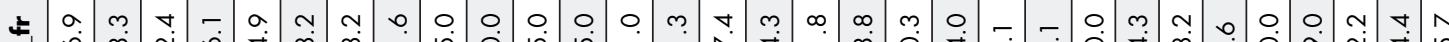

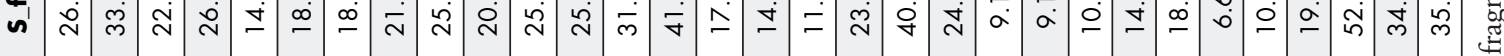

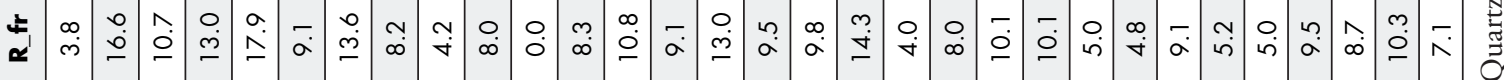

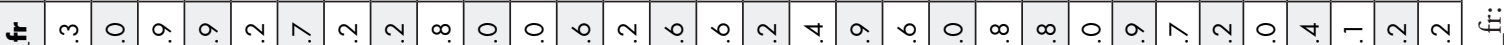
0 o

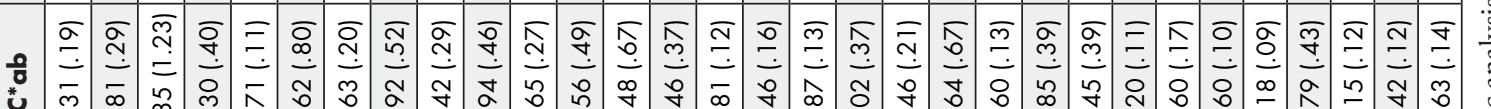

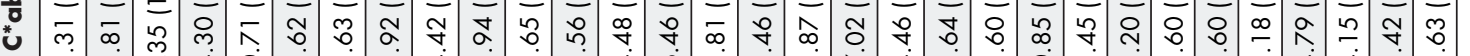

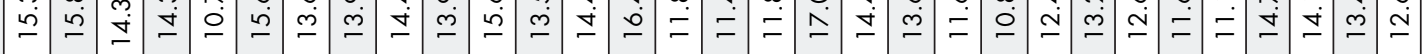

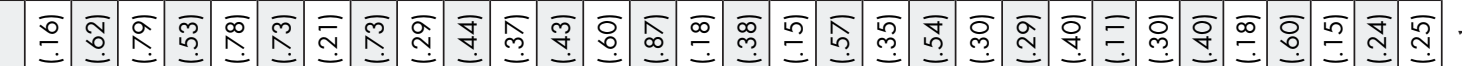

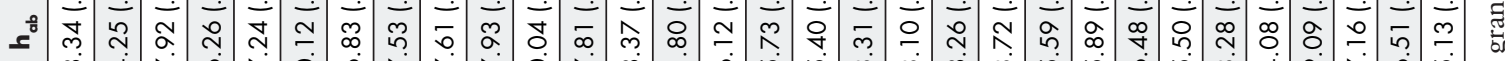

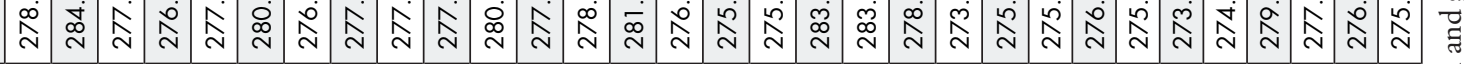

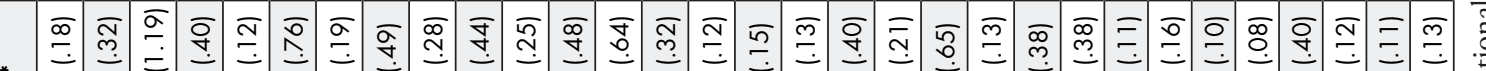

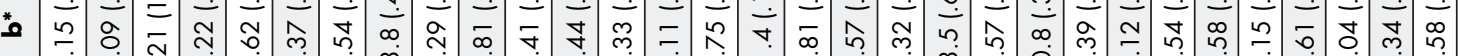

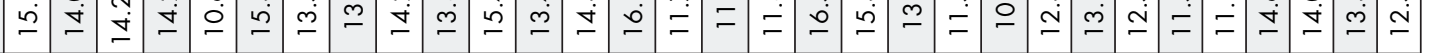

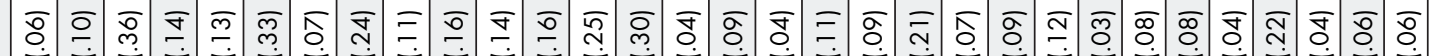

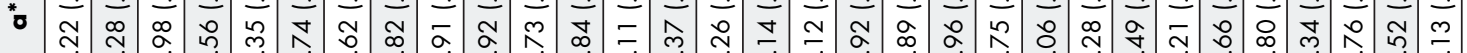

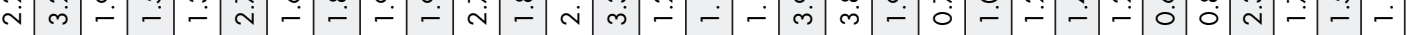

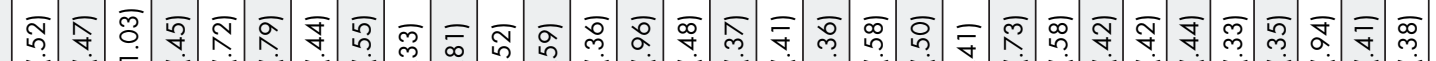

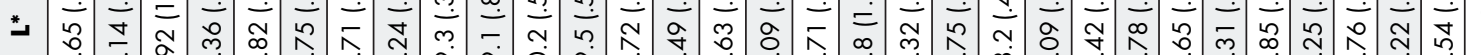

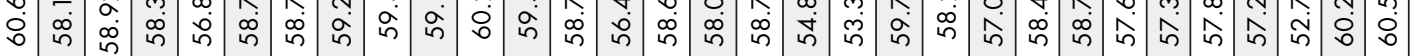

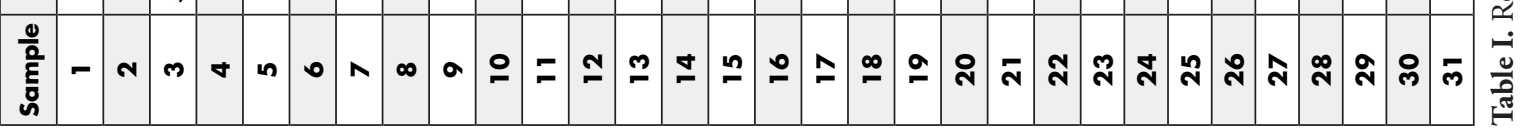




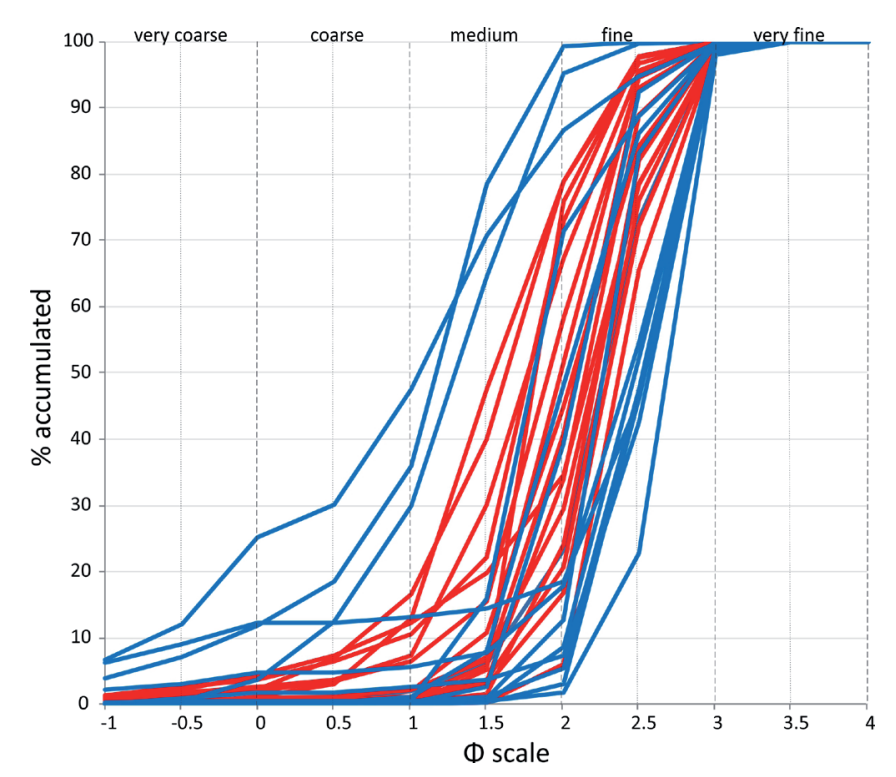

Figure 5. Accumulated grain size curves, where red represents samples from the East coast, and blue, samples from the West coast.
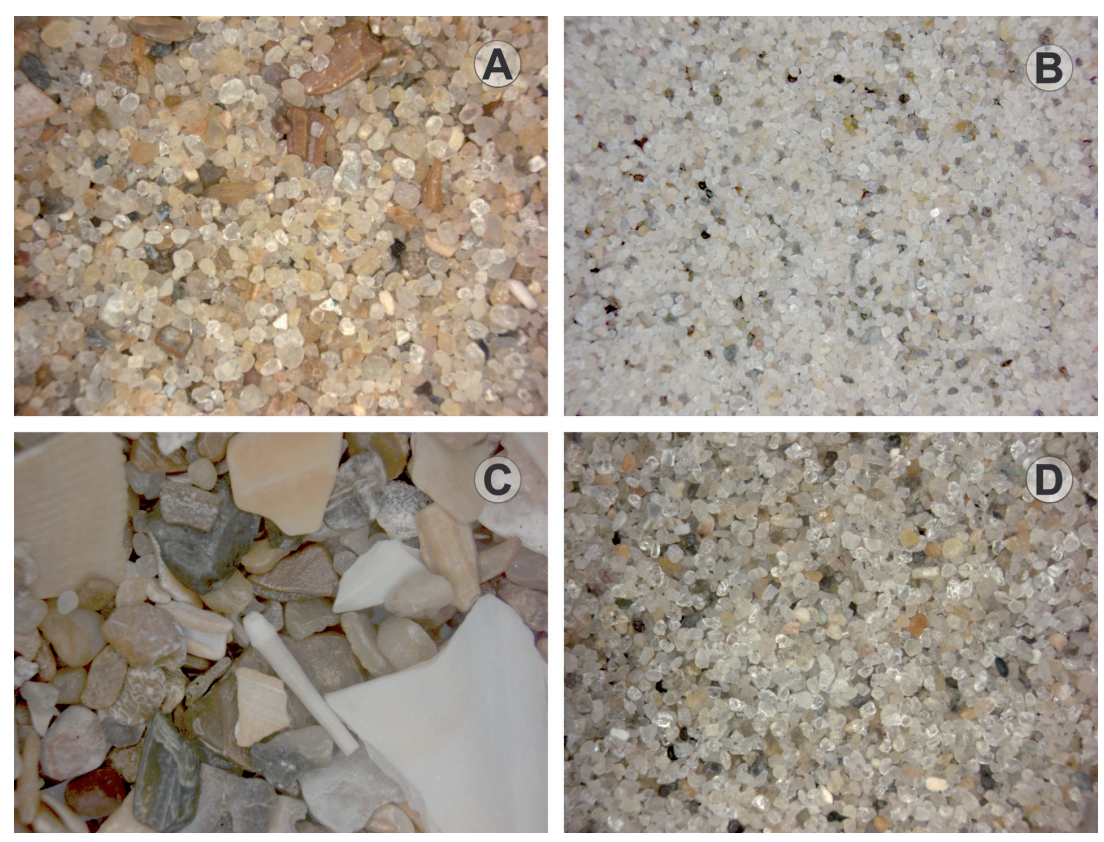

Figure 6. Photographs of the different sands. A) Sample 18, Ostend, mixed sand with quartz, rock and shell fragments. B) Sample 22, Middlelkerke, quartzitic sand. C) Sample 29, Koksijde, sand with a high content of shell fragments. D) Sample 31, De Panne, predominantly quartzitic sand with rock fragments. The long side of each image corresponds to $1.5 \mathrm{~cm}$.

the colorimetric graphics show a population rather homogeneous. The representation of chroma $\mathrm{C}^{*} \mathrm{ab}$ versus hue $\mathrm{h}_{\mathrm{ab}}$ in cylindrical coordinates (Fig. 8) shows all the samples grouped in an area close to the negative $\mathrm{Y}$ axis, corresponding to $-\mathrm{b}^{*}$ values, in the range of blue hue or color intensity, with a red component.

The correlation analysis (Table II) of the three groups of measured variables (color, composition and grain size) shows some interesting associations. Color co- ordinates $\mathrm{a}^{*}$ and $\mathrm{L}^{*}$ show a correlation with grain size, especially for the $\mathrm{a}^{*}$ coordinate, which is strongly positively correlated with medium sand grain sizes, and negatively to fine sand terms. $\mathrm{L}^{*}$ is negatively correlated with grain intervals from coarse to medi-

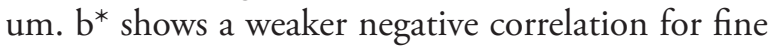
terms. Color is also correlated with rock composition, especially with the quartz and shell fractions. Thus, the content of quartz is inversely proportional to $a^{*}, b^{*}$ and $h_{a b}$, while shell content is directly proportional to these three color coordinates. This 


\begin{tabular}{|c|c|c|c|c|c|c|c|c|c|c|c|c|c|c|c|c|c|c|c|}
\hline$\forall$ & $\stackrel{\simeq}{\simeq}$ & 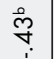 & ঙ্. & $\stackrel{8}{\forall}$ & 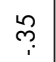 & ભ̊ & $\stackrel{\Delta}{0}$ & 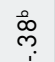 & $\stackrel{\circ}{\circ}$ & $\stackrel{m}{?}$ & $\bar{\Upsilon}$ & $\bar{m}$ & $\stackrel{\nabla}{.}$ & 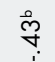 & :o & 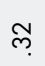 & $\frac{0}{n}$ & $\begin{array}{l}\text { ?. } \\
\text { ?. }\end{array}$ & $\stackrel{8}{0}$ \\
\hline $\begin{array}{l}n \\
\infty \\
\infty \\
0\end{array}$ & \%ొ & 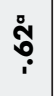 & $\frac{0}{i}$ & :ْ̣: & : & 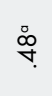 & $\underset{:}{ \pm}$ & $\stackrel{\circ}{\stackrel{\gamma}{\gamma}}$ & 8 & $\stackrel{\infty}{\infty}$ & $\stackrel{m}{?}$ & $\stackrel{\circ}{\stackrel{\rho}{\rho}}$ & p̊op & 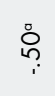 & مْ ْه & 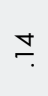 & ळ̊ & $\underset{1}{8}$ & \\
\hline$\stackrel{m}{\infty}$ & 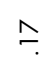 & $\stackrel{\sim}{\stackrel{i}{i}}$ & h̊م & 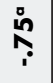 & :0 & $\frac{0}{n}$ & $\stackrel{\simeq}{\because}$ & $\stackrel{\circ}{\stackrel{g}{q}}$ & $\overline{0}$ & $\stackrel{ }{\dddot{T}}$ & 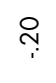 & ơ & $\stackrel{\circ}{\forall}$ & : & $\stackrel{乛}{i}$ & $\bar{ָ}$ & $\stackrel{8}{\circ}$ & & \\
\hline $\begin{array}{l}n \\
\stackrel{n}{*} \\
\stackrel{\theta}{n}\end{array}$ & 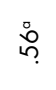 & : & 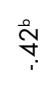 & ơ & $\stackrel{\leftrightarrow}{\mathrm{r}}$ & 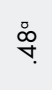 & $\stackrel{\infty}{\circ}$ & $\stackrel{\circ}{\infty}$ & 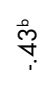 & 总 & ?ִ & :̊م & $\stackrel{\circ}{N}$ & $\stackrel{\Re}{i}$ & ને & \& & & & \\
\hline$\stackrel{N}{\sim}$ & $\stackrel{\infty}{\longrightarrow}$ & $\frac{\Omega}{\nabla}$ & గ̊nم & $\stackrel{8}{\vartheta}$ & గ్రి & $\cong$ & $\cong$ & $\stackrel{\sim}{\sim}$ & $\stackrel{\oplus}{\leftrightarrow}$ & $\cong$ & $\stackrel{m}{?}$ & $=$ & $\hat{o}$ & $\bar{m}$ & $\underset{\sim}{8}$ & & & & \\
\hline$\frac{n}{\theta}$ & ơ & $\frac{\circ}{\infty}$ & $\begin{array}{l}\stackrel{D}{\infty} \\
\stackrel{\infty}{n}\end{array}$ & مٌ & దุ' & : & $\stackrel{\sim}{\text { m. }}$ & $\begin{array}{l}\text { o } \\
\text { ?ִ }\end{array}$ & $\stackrel{\infty}{\sim}$ & $\stackrel{8}{\forall}$ & గִ & ஜ் & هִ & $\underset{-}{8}$ & & & & & \\
\hline $\bar{\theta}$ & $\stackrel{\circ}{\stackrel{\circ}{\infty}}$ & ڤ̊̊ & 侷 & 。̊ & 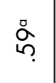 & o̊ & $\bar{m}$ & స్ర & 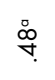 & :ْ & ْ̊ & g் & $\underset{-}{8}$ & & & & & & \\
\hline $\begin{array}{l}n \\
0 \\
0 \\
0\end{array}$ & مِ & 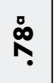 & గi & $\frac{0}{\infty}$ & 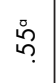 & مُ & $\bar{m}$ & ro & ঙ. & $\frac{0}{n}$ & రై & $\underset{-}{8}$ & & & & & & & \\
\hline$\circ$ & ஜ̊: & $\frac{0}{0}$ & లె & ơ & $\stackrel{\sim}{ฺ}$ & مْ & 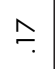 & น̊ & ه్రీ & ণั & $\underset{-}{8}$ & & & & & & & & \\
\hline $\begin{array}{l}n \\
0 \\
0 \\
0\end{array}$ & ్ֶֻ & 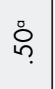 & $\stackrel{\sim}{\sim}$ & ஜ̊n. & $\bar{N}$ & :ִ & $\cong$ & స్ర & \&̊ & $\underset{-}{8}$ & & & & & & & & & \\
\hline $\bar{\theta}$ & $\stackrel{\text { m. }}{.}$ & $\stackrel{m}{m}$. & $\stackrel{n}{\longrightarrow}$ & $\hat{m}$ & $\stackrel{m}{\longrightarrow}$ & స్ర & $\stackrel{\circ}{\curvearrowleft}$ & بْ ْి & $\stackrel{8}{\circ}$ & & & & & & & & & & \\
\hline$\stackrel{\omega^{\prime}}{\prime}$ & ণ্ & :̊ & $\stackrel{\circ}{R}$ & 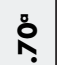 & :o & g & 8 & $\underset{-}{8}$ & & & & & & & & & & & \\
\hline$\stackrel{ \pm}{\alpha}$ & ?ִ & oे & 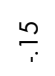 & $\stackrel{\circ}{\longrightarrow}$ & $\stackrel{\infty}{\infty}$ & ঙ্. & $\stackrel{8}{-}$ & & & & & & & & & & & & \\
\hline 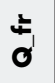 & $\stackrel{m}{m}$ & $\stackrel{\sim}{\stackrel{\sim}{*}}$ & $\frac{0}{i}$ & 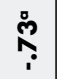 & :̊: & $\stackrel{8}{-}$ & & & & & & & & & & & & & \\
\hline ن유 & $\fallingdotseq$ & مْ & $\begin{array}{l}\text { ळ. } \\
\text { ğ }\end{array}$ & జ̊ & $\underset{\sim}{\stackrel{0}{ }}$ & & & & & & & & & & & & & & \\
\hline$\varepsilon^{\circ}$ & 总 & $\stackrel{\circ}{\circ}$ & مْ & 8 & & & & & & & & & & & & & & & \\
\hline مُ & $\stackrel{m}{?}$ & $\underset{\substack{0 \\
0}}{ }$ & $\stackrel{8}{\circ}$ & & & & & & & & & & & & & & & & \\
\hline *0 & $\frac{0}{n}$ & 8 & & & & & & & & & & & & & & & & & \\
\hline ث & 8 & & & & & & & & & & & & & & & & & & \\
\hline & $\stackrel{*}{*}$ & *0 & قُ & $\varepsilon^{8}$ & $\begin{array}{l}80 \\
8 \\
0\end{array}$ & $\stackrel{ \pm}{\sigma}$ & $\underset{\alpha}{ \pm}$ & $\stackrel{\ddagger}{n}$ & $\bar{\theta}$ & $\begin{array}{l}n \\
0 \\
0 \\
0\end{array}$ & $\stackrel{0}{\theta}$ & $\begin{array}{l}n \\
0 \\
0 \\
\theta\end{array}$ & $\bar{\theta}$ & $\frac{n}{a}$ & $\stackrel{N}{\theta}$ & $\stackrel{n}{\sim}$ & $\infty$ & $\begin{array}{l}n \\
m \\
n\end{array}$ & 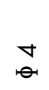 \\
\hline
\end{tabular}



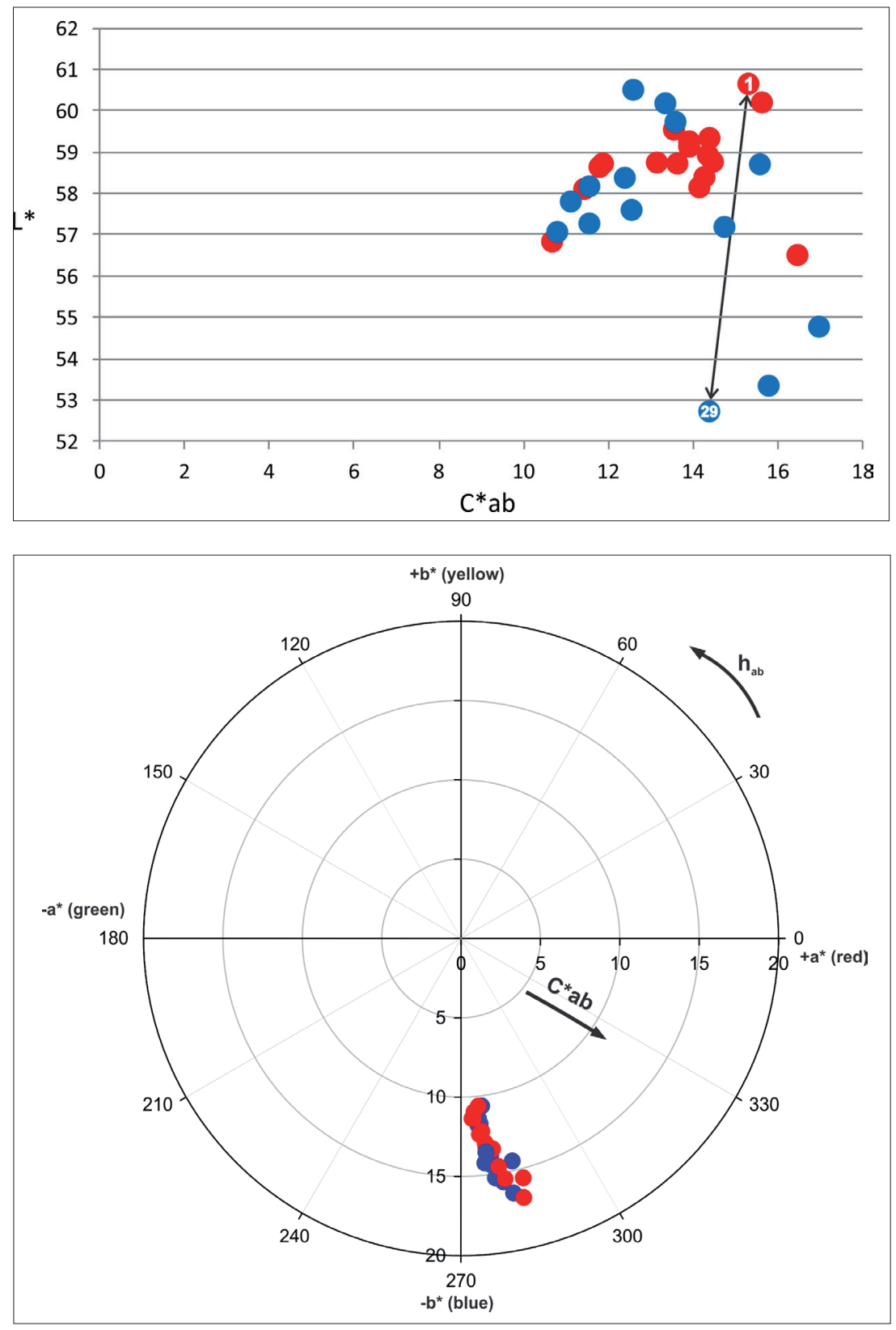

Figure 7. Luminosity $L^{*}$ versus chroma $\mathrm{C}^{*} \mathrm{ab}$. The farther apart the samples are on the $\mathrm{L}^{*}$ axis, the more marked the color differences will be to the human eye. This is the case for sample 29 (bottom) and 1 (top). The distance between two points reflects their $\Delta \mathrm{E}$, calculated with the formula CIEDE2000, which uses the parameters from this graph. Red: samples from the east coast; blue: samples from the west coast.
Figure 8. Representation of chroma $\left(\mathrm{C}^{*} \mathrm{ab}\right)$ and hue $\left(\mathrm{h}_{\mathrm{ab}}\right)$ on cylindrical coordinates. The luminosity $\mathrm{L}^{*}$ value is 0 at the center of the diagram. Red: samples from the East coast; blue: samples from the West coast. means that as higher is the quartz content, the color, and especially the hue of the sand will trend to be less intense, while the shell content will point to the opposite direction. Other correlations can be found between the granulometry and the rock content. Quartz and shell contents are inversely and directly proportional to the grain size. Finally, within each group of measured variables there are some correlations of minor importance for this work, like the inversely proportion relation between quartz and shell fragments, and between the grain size intervals.

\section{Conclusions}

Sand color is an aesthetical parameter closely linked with the composition and granulometry, and usually is not taken into account when facing a nourishment work, which has lead in some occasions to severe problems. This work presents a methodology to measure the color of a beach sand before a nourishment work. For this, it is very important to define firstly the area and minimum number of measures to be made. These two parameters were found to be $95 \mathrm{~cm}^{2}$ and 21 measures. 
Sands from the Belgium coast are rather homogeneous in granulometry, composition and color. A standard sand is like to be medium size grain, composed by quartz, shell fragments and rock fragments in decreasing order. Color coordinates are in the interval of 50 to $60 \mathrm{~L}^{*}$ for luminosity, 0.5 to 4.0 for $\mathrm{a}^{*}$, and 10.5 to 16.5 for $\mathrm{b}^{*}$. There are no clear distinction between colors of the West and East coast sands, but regarding to granulometry West sands present a wider range than the East sands. Color difference calculated for the two most dissimilar samples using the CIEDE2000 formula shows a value of $\Delta \mathrm{E}=7.45$, which is considered to be noticeable to human eye. Nevertheless, most of the sands are grouped in the Luminosity $L^{*}$ versus chroma $C^{*}$ ab diagram, with small $\Delta \mathrm{E}$ values among them. Granulometry has shown to have influence on sand color. Samples with coarser grain size also have the highest proportions of shell fragments, presenting tones tending to red, while fine-grained sands tend to greenbrown tones. These sands are mainly composed of quartz and rock fragments.

In general, composition and granulometry are rather similar, so in case sands from different points of the Belgian coast would be combined, the dynamic processes held at the beach would probably homogenize them in color in a relatively short period of time. However, if composition and granulometry would be different, the homogenization in color might not get place. The color of the sand is mainly correlated with the mineral components, especially quartz and shell fragments, and then with the granulometry. Coarse and medium sands have more lightness and hue trending to the red $\left(+a^{*}\right)$, while fine and very fine sands are darker with colors tending to the blue $\left(-b^{*}\right)$.

\section{References}

Anthony, E. J., Cohen, O. and Sabatier, F. (2011): Chronic offshore loss of nourishment on Nice beach, French Riviera: A case of over-nourishment of a steep beach? Coastal Engineering, 58: 374-383.

Anthony, E. J., and Héquette, A. (2007): The grain-size characterisation of coastal sand from the
Somme estuary to Belgium: Sediment sorting processes and mixing in a tide -and storm-dominated setting. Sedimentary Geology, 202: 369-382.

Boronkay, G. (2014): Colour Conversion Centre 4.0a.

Capobianco, M., Hanson, H., Larson, M., Steetzel, H., Stive, M. J. F., Chatelus, Y., AarnInKHOF, S. and Karambas, T. (2002): Nourishment design and evaluation: applicability of model concepts. Coastal Engineering, 47: 113-135.

CiE_TC_1-57 (2013): Colorimetry-Part 6: CIEDE2000 Colour-Difference Formula.

Cooke, B. C., Jones, A. R., Goodwin, I. D. and Bishop, M. J. (2012): Nourishment practices on Australian sandy beaches: A review. Journal of Environmental Management, 113: 319-327.

Charlier, R. H., Chaineux, M. C. P. and Morcos, S. (2005): Panorama of the history of coastal protection. Journal of Coastal Research, 21: 79-111.

Charlier, R. H., and De Meyer, C. P. (2000): Ask nature to protect and build-up beaches. Journal of Coastal Research, 16: 385-390.

Charlier, R. H., and De Meyer, C. P. (1989): Coastal defense and beach renovation. Ocean \& Shoreline Management, 12: 525-543.

Charlier, R. H., and De Meyer, C. P. (1992): Tourism and the coastal zone: The case of Belgium. Ocean \& Coastal Management, 18: 231-240.

De Meyer, C. P. (1989): Case studies in coastal protection: Zeebrugge (Belgium) and Bali (Indonesia). Ocean \& Shoreline Management, 12: 517-524.

Hamm, L., Capobianco, M., Dette, H. H., Lechuga, A., Spanhoff, R. and Stive, M. J. F. (2002): A summary of European experience with shore nourishment. Coastal Engineering, 47: 237-264.

Hanson, H., Brampton, A., Capobianco, M., Dette, H. H., Hamm, L., Laustrup, C., Lechuga, A. and Spanhoff, R. (2002): Beach nourishment 
projects, practices, and objectives - a European overview. Coastal Engineering, 47: 81-111.

Hatcher, A., Hill, P., Grant, J. and Macpherson, P. (2000): Spectral optical backscatter of sand in suspension: effects of particle size, composition and colour. Marine Geology, 168: 115-128.

Hоввs, C. H. (2012): The Beach Book: Science of the Shore. Columbia University Press.

Milton, S. L., Schulman, A. A. and Lutz, P. L. (1997): The effect of beach nourishment with aragonite versus silicate sand on beach temperature and loggerhead sea turtle nesting success. Journal of Coastal Research, 13: 904-915.

Pranzini, E., Simonetti, D. and Vitale, G. (2010): Sand Colour Rating and Chromatic Compatibility of Borrow Sediments. Journal of Coastal Research, 26: 798-808.

Pranzini, E., and Vitale, G. (2011): Beach Sand Colour: the Need for a Standardised Assessment Procedure. Journal of Coastal Research, 61: 66-69.

Roca, E., Riera, C., Villares, M., Fragell, R. and JunYent, R. (2008): A combined assessment of beach occupancy and public perceptions of beach quality: A case study in the Costa Brava, Spain. Ocean \& Coastal Management, 51: 839-846.

Roman-Sierra, J., Muñoz-Pérez, J. J. and NavarRO-Pons, M. (2014): Beach nourishment effects on sand porosity variability. Coastal Engineering, 83: 221-232.

Swift, D. J. P., and Boemmer, W. R. (1972): Brown and gray sands on the Virginia shelf: Color as a function of grain size. Geological Society of America Bulletin, 83: 877-883.

Tsujimoto, G., and Tamai, M. (2013): Analysis of beach sand color and its application to sedimentation, 7th International Conference on Asian and Pacific Coasts (APAC 2013), Hasanuddin University Press, Bali, Indonesia: 141-146.

Walden, J., and White, K. (1997): Investigation of the controls on dune colour in the Namib Sand Sea using mineral magnetic analyses. Earth and Planetary Science Letters, 152: 187-201.

Wyszecki, G., and Stiles, W. S. (1982): Color Science. Concepts and Methods, Quantitative Data and Formulae. John Wiley \& Sons Inc., New York. 